\title{
Evaluasi Program Pemberdayaan Masyarakat Melalui Bank Sampah Mawar Sejadi di Kelurahan Sijambi Kecamatan Datuk Bandar Kota Tanjung Balai Evaluation of Community Empowerment Program Through Mawar Sejadi Waste Bank in Sijambi Village, Datuk Bandar District, Tanjung Balai City
}

Maria Santifa1), Warjio's), Dumasari Harahap"3) \& Isnanini4)

1) Pasca Sarjana Magister Ilmu Administrasi Publik Universitas Medan Area, Indonesia

2) Departemen Ilmu Politik, Fakultas Ilmu Sosial dan Ilmu Politik, Universitas Sumatera Utara, Indonesia

3) Pendidikan dan Latihan, Provinsi Sumatera Utara, Indonesia 4) Fakultas Hukum, Universitas Medan Area, Indonesia

\begin{abstract}
Abstrak
Tujuan penelitian tersebut adalah: Untuk mengetahui Bagaimana evaluasi program pemberdayaan masyarakat melalui bank sampah Mawar Bestari di Kelurahan Sijambi Kecamatan Datuk Bandar Kota Tanjungbalai. Untuk mengetahui Faktor-faktor apa saja yang menjadi penghambat dalam evaluasi program pemberdayaan masyarakat melalui bank sampah Mawar Bestari di Kelurahan Sijambi Kecamatan Datuk Bandar Kota Tanjungbalai. Jenis penelitian ini bersifat deskriptif kualitatif dengan melakukan pengamatan langsung atau observasi, wawancara dan dokumentasi. Metode deskriptif adalah metode yang digunakan untuk meneliti status kelompok manusia, suatu obyek, suatu kondisi dan suatu sistem pemikiran serta peristiwa yang akan terjadi. Hasil penelitian menunjukkan bahwa Evaluasi Program Pemberdayaan Masyarakat melalui Bank Sampah Mawar Bestari di Kelurahan Sijambi berjalan cukup optimal, dengan terwujudnya tujuan evaluasi yaitu : mampu mewujudkan kerjasama yang baik antara pihak Kelurahan dengan masyarakat sehingga program Bank Sampah terlaksana dengan baik dan pemanfaatannya sangat dirasakan oleh masyarakat itu sendiri khususnya masyarakat Kelurahan Sijambi.
\end{abstract}

Kata Kunci: Evaluasi Program, Pemberdayaan Masyarakat, Bank Sampah.

\begin{abstract}
As for the research objectives: To find out how the community empowerment program evaluates through waste bank Mawar Bestari in Sijambi Village Datuk Bandar Kota Tanjungbalai District. To find out what factors are the obstacles in the evaluation of community empowerment programs through the Mawar Bestari waste bank in Sijambi Village, Datuk Bandar Kota District, Tanjungbalai. This type of research is descriptive qualitative by making direct observations or observations, interviews and documentation. Descriptive method is a method used to examine the status of a human group, an object, a condition and a system of thoughts and events that will occur. The results showed that the Community Empowerment Program Evaluation through the Mawar Bestari Garbage Bank in Sijambi Village runs quite optimally, with the realization of the evaluation objectives, namely being able to realize good cooperation between the Kelurahan and the community so that the Waste Bank program is implemented well and the community feels the utilization especially the Sijambi Village community.
\end{abstract}

Keywords: Program Evaluation, Community Empowerment, Waste Bank.

How to Cite: Santifa M, Warjio, Harahap D \& Isnaini, (2020). Evaluasi Program Pemberdayaan Masyarakat Melalui Bank Sampah Mawar Sejadi di Kelurahan Sijambi Kecamatan Datuk Bandar Kota Tanjung Balai Strukturasi: Jurnal Ilmiah Magister Administrasi Publik, 1(1): 89-98,

*E-mail: mariasantifa@gmail.com $I S S N$ 


\section{PENDAHULUAN}

Saat ini pengelolaan sampah sebahagian besar Kota masih menimbulkan permasalahan yang sulit dikendalikan. Selain itu cara masyarakat dalam mengelola sampah yang masih bertumpu pada pendekatan kumpul, angkut, dan dibuang ke Tempat Pembuangan Akhir. Disamping itu Masyarakat masih memandang sampah sebagai barang sisa yang tidak berguna dan tidak memiliki nilai sebagai sumber daya yang bisa dimanfaatkan. Keterbatasan Kemampuan Dinas Kebersihan dalam menangani permasalahan sampah tersebut menjadi awal dari semakin menurunnya sistem penanganan permasalahan tersebut. Hal tersebut semakin dipersulit dengan terbatasnya lahan TPA sampah, jumlah sarana pengangkutan, Jumlah karyawan serta pengelolaan sampah di TPA yang tidak sesuai dengan kaidah-kaidah yang ramah lingkungan.

Pemerintah Daerah sebagai pihak yang berwewenang dalam pengelolaan sampah memiliki tanggung jawab yang besar dalam menyelesaikan persoalan pengelolaan sampah di daerahnya masing-masing baik itu dalam pengelolaan sampah didaerahnya masing-masing baik itu dalam hal strategi pengelolaan ,izin pengelola dan permasalahan volume sampah. Dalam hal Undang-Undang Nomor 18 Tahun 2008 sebagai landasan dari pengelolaan sampah ditekankan bahwa sampah telah menjadi permasalahan Nasional sehingga pelaksanaannya perlu dilakukan secara komprehensif dan terpadu dari hulu ke hilir sehingga memberikan mamfaat secara Ekonomi, sehat bagi masyarakat, dan aman bagi lingkungan, serta dapat mengubah prilaku Masyarakat. Dalam lingkup Pemerintah Daerah Kota Tanjungbalai salah satu strategi dalam pengelolaan sampah adalah dengan sistem 3 R yaitu (Reduce, Reuse dan Recycle). Kota Tanjungbalai merupakan salah satu Kota terpadat di Asia Tenggara dengan jumlah Penduduk 169.773jiwa.

Maka dari itu, peneliti menemukan fenomena-fenomena yang terjadi di Kelurahan Sijambi Kota Tanjungbalai sebagai berikut :

Kurangnya tingkat kesadaran masyarakat di Kelurahan Sijambi Kota Tanjungbalai mengenai sampah khususnya sampah rumah tangga maupun kantoran yang setiap harinya berjumlah 118 Ton/hari. Melalui Pemerintah Kota Tanjungbalai melakukan upaya untuk menaikkan tingkat kesadaran masyarakat akan sampah dari 31 kelurahan yang tersebar di seluruh Kota Tanjungbalai hanya 2 Kelurahan yang mampu melakukan akan kesadaran masyarakat mengenai sampah, sehingga pemerintah Kota Tanjungbalai melakukan sosialisasi berupa penyediaan Bank Sampah di kedua Kelurahan. Pemerintah Kota Tanjungbalai terus berupaya melakukan evaluasi program-program mengenai Bank Sampah khususnya Dikelurahan Sijambi misalnya didapatkan informasi bahwa masih ada beberapa masalah dalam pelaksanaan bank sampah (Siregar et .all, 2016). Masalah tersebut antara lain belum terbentuknya struktur pengurus yang terpadu, masyarakat belum sadar akan pentingnya memilah dan mengelola sampah, pengetahuan masyarakat mengenai Bank Sampah juga masih terbatas. kurangnya partisipasi masyarakat dalam mengelola bank sampah juga menjadi penyebab pelaksanaan yang belum optimal. Informasi lain didapatkan dari masyarakat sekitar kelurahan Sijambi Kecamatan Datuk Bandar Kota Tanjungbalai bahwa mereka belum merasakan dampak positif yang signifikan sejak adanya bank sampah mawar bestari yang sudah tersedia selama ini. 
Minimnya alat-alat pengangkutan sampah, sehingga mempersulit petugas lapangan dalam pengangkutan sampah, disamping masih minimnya kelompok Bank Sampah serta alat pengangukatan sehingga sulit untuk melakukan suatu gerakan. Tong sampah merupakan hal penting bagi masayarakat agar tidak membuang sampah sembarangan dan hal ini masih kurang terkelola dengan baik, hal ini pihak Pemerintah Kota Tanjungbalai mampu memberikan tong sampah di setiap kelurahan-kelurahan serta menetukan jadwal pengangkutan sampah dan informasi ini seharus di beritahukan terhadap warga agar sampah tidak menumpuk di setiap kelurahan.

Berdasarkan hasil observasi dan fenomena-fenomena seperti uraian di atas, maka penulis tertarik untuk melaksanakan penelitian dengan Judul: "Evaluasi Program Pemberdayaan Masyarakat Melalui Bank Sampah Mawar Bestari di Kelurahan Sijambi Kecamatan Datuk Bandar Kota Tanjungbalai".

\section{METODE PENELITIAN}

\section{Lokasi dan Waktu Penelitian}

Penelitian ini dilakukan di Kantor Kelurahan Sijambi Kecamatan Datuk Bandar Kota Tanjung Balai, Sumatera Utara. Dan waktu penelitian direncanakan mulai Desember 2018 sampai dengan bulan Februari 2019.

\section{Bentuk Penelitian}

Jenis penelitian ini bersifat deskriptif kualitatif dengan melakukan pengamatan langsung atau observasi, wawancara dan dokumentasi. Metode deskriptif adalah metode yang digunakan untuk meneliti status kelompok manusia, suatu obyek, suatu kondisi dan suatu sistem pemikiran serta peristiwa yang akan terjadi (Burgin, Burhan, 2012: 83).

\section{Teknik Pengumpulan Data}

a. Lilbrary Research (Penelitian Kepustakaan)

Penelitian kepustakaan ini dalam penelitian ini adalah sebagai salah satu cara dalam proses pengumpulan data dengan membaca buku-buku dan bahan bacaan lainnya yang relevan dengan masalah yang akan di teliti.

\section{b. Field Research (Penelitian Lapangan)}

Dalam riset atau penelitian lapangan yang akan di lakukan dalam mencari data dan infomasi di mana penelitian di lakukan secara langsung terjun ke lapangan dengan melakukan cara sebagai berikut :

1) Wawancara, yaitu teknik pengumpulan data dengan mengajukan pertanyaanpertanyaan langsung kepada pihak-pihak yang berhubungan dengan penelitian yang dilakukan dan selanjutnya akan disebut sebagai informan.

2) Observasi, yaitu kegiatan mengamati secara langsung objek penelitian dengan mencatat gejala-gejala yang ditemukan dilapangan serta menjaring data yang tidak terjangkau. 
3) Dokumentasi berupa Foto, data saat wawancara dengan pihak terkait dalam memberikan informasi dalam penelitian.

\section{Informan Penelitian}

Informan kunci adalah mereka yang mengetahui dan memiliki berbagai informasi pokok yang diperlukan dalam penelitian atau informan yang mengetahui secara mendalam permasalahan yang diteliti. Adapun Informan Kunci dalam penelitian ini ialah:

a. Kepala Dinas Lingkungan Hidup Kota Tanjungbalai

b. Camat Datuk Bandar

c. Lurah Sijambi Kecamatan Datuk Bandar

Informan tambahan yaitu mereka yang memberikan informasi walaupun tidak terlibat di dalam interaksi sosial yang diteliti. Adapun informan tambahan dalam penelitian ini adalah Kepala Lingkungan, TP PKK dan masyarakat setempat.

\section{Teknik Analisis Data}

a. Pengumpulan Data

Penelitian mencatat semua data secara objektif dan apa adanya sesuai dengan hasil observasi dan wawancara dilapangan.

b. Reduksi Data

Reduksi data yaitu memilih hal-hal pokok yang sesuai dengan fokus penelitian. Reduksi merupakan suatu bentuk analisis data yang menggolongkan, mengarahkan, membuang yang tidak perlu dan mengorganisasikan data -data yang telah di reduksi, memberikan gambaran yang lebih tajam tentang hasil pengamatan dan mempermudah peneliti untuk mencarinya jika sewaktu - waktu diperlukan.

c. Penyajian Data

Penyajian data merupakan sekumpulan informasi yang tersusun, memungkinkan adanya penarikan kesimpulan dan pengambilan tindakan.

d. Pengambilan keputusan atau verifikasi

Setelah data disajikan, maka dilakukan pengambilan keputusan dan verifikasi. Untuk itu diusahakan untuk mencari pola, model, tema, hubungan, persamaan, hal-hal yang sering muncul, dan lain sebagainya. Jadi dari data tersebut diusahakan untuk mengambil suatu kesimpulan. Verifikasi dapat dilakukan dengan keputusan, didasarkan pada reduksi data, dan penyajian data yang merupakan jawaban atas masalah yang diangkat dalam penelitian.

\section{HASIL DAN PEMBAHASAN}

1. Evaluasi Program Pemberdayaan Masyarakat Melalui Bank Sampah Mawar Bestari di Kelurahan Sijambi Kecamatan Datuk Bandar Kota Tanjung Balai

a. Tujuan Evaluasi Program Pemberdayaan Masyarakat Melalui Bank Sampah

Untuk menentukan sasaran evaluasi program Bank Sampah yang dilaksanakan oleh Kelurahan Sijambi, peneliti perlu mengenali program 
pemberdayaan Bank Sampah Mawar Bestrai dengan baik, terutama komponenkomponennya, karena yang menjadi sasaran evaluasi bukan program secara keseluruhan tetapi komponen atau bagian program (Gosawa \& Ritonga, 2015). Tujuan umum harus dijabarkan menjadi tujuan khusus, maka sasaran peneliti diarahkan pada komponen agar pengamatannya dapat lebih cermat dan data yang dikumpulkan lebih lengkap. Untuk itulah maka penelitihendaknya memiliki kemampuan mengidentifikasi komponen program pemberdayaan masayarakat melalui Bank Sampah yang akan dievaluasi

Penulis melakukan wawancara dengan Ibu Rosidah SH, sebagai informan Utama yang merupakan Pejabat Kelurahan di Kelurahan Sijambi, berikut ini wawancara yang dituangkan penulis:

Apa Tujuan Program Pemberdayaan Masyarakat dalam mendirikan Bank Sampah di Kelurahan Sijambi?

"Tujuan didirikan bank sampah ini adalah untuk ikut melestarikan lingkungan. Sebab, tanpa dukungan penuh seluruh lapisan masyarakat, Kepala Lingkungan, Lurah, Camat, Dinas Lingkungan Hidup dan OPD (Organisasi Perangkat Daerah) terkait upaya Pemko Tanjungbalai untuk melestarikan lingkungan hidup tidak akan berhasil. Dukungan itu bisa diwujudkan dalam bentuk melakukan tidak membuang sampah sembarangan serta senantiasa menjaga kebersihan lingkungan sekitar tempat tinggal"(hasil Wawancara dengan Kadis Lingkungan Hidup sebagai Informan Kunci Selaku Informan Kunci Diruang Kerja. Tanggal 1 Februari 2019, Pukul 09.10 Wib).

Selanjutnya penulis melaukan wawancara dengan Camat selaku Informan Kunci dalam penelitian ini, maka hasil wawancaranya adalah sebagai berikut:

"Tujuannya adalah untuk melatih masyarakat agar kesadaran dengan sampah, bahwa sampah yang selama ini dibuang begitu saja namun memiliki banyak manfaat tanpa kita sadari yang ternyata banyak manfaat sampah. Di satu sisi tujuan dibentuknya Bank Sampah ini atas keprihatinan pihak Kelurahan Sijambi terhadap sampah yang sekian hari semakin bertambah dengan melalui program Bank Sampah saya selaku Lurah di Kelurahan Sijambi akan terus mengkampanyekan akan pentingnya sampah melalui program Bank Sampah yang saat ini berjalan dengan lancar. (hasil Wawancara dengan Ibu Camat Dra. H. Siti Naisyah Informan Kunci Selaku Informan Utama Diruang Kerja. Tanggal 1 Februari 2019, Pukul 09.30 Wib).

Dari penjelasan diatas peneliti menjelaskan bahwa dengan adanya program Bank Sampah Mawar Bestari Kelurahan Sijambi maka tujuan dibangunnya Bank Sampah sebenarnya adalah strategi untuk membangun kepedulian masyarakat agar dapat berkawan dengan sampah untuk mendapatkan manfaat ekonomi langsung dari sampah (Kusumantoro, 2013). Jadi, bank sampah tidak dapat berdiri sendiri melainkan harus dijalankan secara bersama sehingga manfaat langsung yang dirasakan tidak hanya ekonomi, namun pembangunan lingkungan yang bersih, hijau dan sehat. Bank Sampah memiliki beberapa manfaat bagi manusia dan lingkungan hidup, seperti membuat lingkungan lebih bersih, menyadarkan masyarakat akan pentingnya kebersihan, dan membuat sampah menjadi barang ekonomis. Manfaat bank sampah untuk masyarakat adalah dapat menambah penghasilan masyarakat. 
b. Proses Evaluasi Program Pemberdayaan Masyarakat

Penulis kembali melakukan wawancara dengan Ibu Rosidah SH, sebagai informan Utama yang merupakan Pejabat Kelurahan di Kelurahan Sijambi, berikut ini wawancara yang dituangkan penulis:

Bagaimana proses pemberdayaan masyarakat melalui program Bank Sampah Mawar Bestari yang ada di Kelurahan Sijambi ini?

Jawab :"Ada beberapa tahapan-tahapan sebelum berdirinya Program Bank Sampah Mawar Bestari di Kelurahan Sijambi yaitu saya sebagai lurah harus mengetahui terlebih dahulu berbagai permasalahan-permasalahan dikalangan masyarakat, awalnya saya selaku Lurah membentuk berupa Tim-tim yang akan turun kelapangan serta membentuk kelompok-kelompok masyarakat dalam program Bank Sampah ini agar kedepannya bisa berjalan dengan baik sesuai program Walikota Tanjungbalai tentang masalah sampah."(hasil Wawancara dengan Informan Kunci Ibu Dra. H. Siti Naisyah Diruang Kerja. Tanggal 1 Februari 2019, Pukul 09.15 Wib).

Selanjutnya penulis melakukan wawancara dengan Seksi Pembangunan selaku Informan Utama dalam penelitian ini, maka hasil wawancaranya adalah sebagai berikut:

"Proses awal adalah melakukan sosialisas terlebih dahulu pada masyarakat, baik melalui RT dan RW sebelumnya Bu Lurah menginstruksikan pada RT dan RW agar mengumpulkan masyarakat di Balai Desa untuk mengikuti sosialisasi mengenai program Bank Sampah yang telah ditentukan, dimana sesuai intruksi Bu Lurah kami langsung membentuk berupa kelompok-kelompok. (hasil Wawancara dengan Seksi Pembangunan Selaku Informan Utama Diruang Kerja. Tanggal 1 Februari 2019, Pukul 09.30 Wib).

Penulis juga melakukan wawancara dengan Masyarakat khususnya Kelompok Bank Sampah Mawar Bestari selaku Informan Tambahan dalam penelitian ini, maka hasil wawancaranya adalah sebagai berikut:

"Proses pemberdayaan masyarakat melalui program Bank Sampah Mawar Bestari yang ada di Kelurahan Sijambi yang diciptakan oleh Kelurahan sudah sangat bagus, kami masyarakat yang bergabung dengan berbagai kelompok-kelompok sangat mendukung proses yang dibuat Ibu Lurah sehingga bisa terciptanya Bank Sampah ini sehingga muncul suatu kekompakan diantara kami."(hasil Wawancara dengan Informan Tambahan Ibu Rina Rasyid di Pondok Bank Sampah Mawar Bestari. Tanggal 1 Februari 2019, Pukul 14.15 Wib).

Dari pernyataan informan diatas bahwa konsep pemberdayaan muncul sebagai konsep alternatif pembangunan yang pada intinya menekankan otonomi pengambilan keputusan dari suatu kelompok masyarakat yang berlandaskan sumber daya pribadi, partisipatif, demokratis, dan pembelajaran sosial melalui pengalaman langsung. Konsep pemberdayaan sekaligus mengandung konteks pemihakan kepada lapisan masyarakat yang berada di lapisan paling bawah. Menurut Wrihatnolo, dan Riant (2011:38-39), beberapa alasan mengapa usaha pemberdayaan perlu dilakukan 
adalah, pertama, demokratisasi proses pembangunan. Konsep pemberdayaan program Bank Sampah di Kelurahan Sijambi Kota Tanjungbalai memberikan peluang sebesar-besarnya kepada lapisan masyarakat paling bawah untuk terlibat dalam pengalokasian sumber daya pembangunan. Pembangunan digerakkan oleh masyarakat sekaligus menjadi wahana pembelajaran pencerdasan bagi rakyat untuk mengenali kebutuhannya sendiri serta melaksanakan dan melestarikan upaya untuk memenuhi kebutuhannya itu. Penerapan konsep program pemberdayaan dengan demikian memberikan efek positif dalam penyelenggaraan ketatanegaraan secara baik.

\section{c. Partisipasi Masyarakat Dalam Program Pemberdayaan Bank Sampah}

Hasil observasi yang dilaukan oleh penulis dilapangan bahwasalah satu program pemberdayaan yang ada di Kelurahan Sijambi adalah program pemberdayaan melalui Bank Sampah. Program pemberdayaan melalui pembentukan Bank Sampah adalah program yang bertujuan untuk memandirikan, memberdayakan dan memanfaatkan sampah rumahan yang sejenis sampah organik dan non organik yang dimiliki oleh masyarakat Kelurahan Sijambi untuk dimanfaatkan sebagai penambahan bidang ekonomi yang memiliki nilai tertentu, khususnya diperuntukkan untuk masyarakat Kelurahan Sijambi. Namun demikian masyarakat Kelurahan Sijambi masih mengalami kesulitan mengajak masyarakat dalam program pemungutan sampah rumahan dan bergabung di komunitas Bank Sampah Mawar Bestari, walaupun pihak Kelurahan sudah melakukan berbagai sosialisasi, pertemuan-pertemuan, pelatihan-pelatihan namun belum semua masyarakat bisa diajak untuk berpartisipasi dalam pengumpulan sampah-sampah rumahan, yang sementara pihak Kelurahan Sijambi sudah menyediakan lokasi dan tempat khusus pemungutan sampah serta berbagai alat-alat pengangkut sampah agar kepedulian msayarakat dengan sampah lebih perduli dengan kesehatan.

Menurut Septyasa (2013: 63) dalam penelitiannya tentang bentuk-bentuk partisipasi masyarakat dalam program Kelurahan Sijambi mengatakan bahwa bentuk-bentuk partisipasi masyarakat dilihat dari tahapan-tahapan pelaksanaan:

Tahap perencanaan dalam tahap ini partisipasi masyarakat dapat diketahui melalui keaktifan menghadiri sosialisasi, musyawarah, penyuluhan dan pelatihan yang diadakan pemerintah desa, dimana dalam tahap perencanaan tersebut masyrakat juga ikut menyumbang pikiran. Hasil dari partisipasi masyarakat dalam tahapan perencanaan ini salah satunya ialah terbentuknya organisasi kepengurusan tingkat desa.

Tahap pelaksanaan dalam tahap ini partisipasi masyarakat dapat diketahui melalui keikutsertaan masyarakat dalam menciptakan lingkungan yang bersih dengan melakukan program perilaku hidup bersih dan sehat, mengikuti kegiatan pengumpulan berbagai sampah dan mengikuti kegatan kerja bakti yang dilakukan oleh seluruh masyarakat dan penyediaan Pondok-pondok Bank Sampah sebagai tempat menyaring sampah-sampah yang organik dan non organik. 
Tahap penilaian dalam tahap keterlibatan masyarakat dalam menilai sejauh mana pelaksanaan pembangunan sesuai dengan rencana dan sejauh mana hasil dari pembangunan tersebut dalam pemenuhan kebutuhan masyarakat.

\section{d. Dampak Evaluasi Program Pemberdayaan Masyarakat}

Selanjutnya Penulis melakukan wawancara dengan Ibu Rosidah SH, sebagai informan Utama yang merupakan Pejabat Kelurahan di Kelurahan Sijambi, berikut ini wawancara yang dituangkan penulis:

Dengan dibentuknya Program Kelompok Bank Sampah Mawar Bestari, apakah pihak Kelurahan melakukan pelatihan kreatifitas sampah seperti kerajinan tangan serta memiliki aspek ekonomi?

Jawab: "Ya. Saya selaku Lurah di Kelurahan Sijambi ini dengan melalui program Bank Sampah khususnya kepada kelompok Bank Sampah Mawar Bestari mereka sudah kami buat berbagai pelatihan-pelatihan mengenai sampah organik dan non organik, dari berbagai sampah yang dikumpulkan mereka saya sebagai Lurah tentunya membuat serupa pelatihan-pelatihan seperti kreatifitas kerajinan tangan yang tentunya memiliki aspek ekonomis. Pihak Kelurahan akan membantu dari segala aspek pembuatan kerajinan tangan mereka yang berasal dari sampah yang dikumpulkan, dan membatu bagaimana cara memasarkan ke masyarakat banyak sisi pemasaran yang baik sehingga hasil yang didapat dari pengumpulan sampah bisa dirasakan oleh para kelompok-kelompok Bank Sampah."(hasil Wawancara dengan Ibu Dra. H. Siti Naisyah Informan Kunci Selaku Informan Kunci Diruang Kerja. Tanggal 1 Februari 2019, Pukul 10.00 Wib).

Hasil dari suatu program itu berjalan dengan baik maupun tidak tergantung bagaimana penilaian masyarakat itu sendiri. Strategi penyelenggaraan program di masyarakat erat kaitannya dengan pemberdayaan di masyarakat yang menciptakan kesempatan kerja dan peluang berusaha yang memberikan pendapatanyang memadai bagi masyarakat. Suatu pemberdayaan ditujukan untuk membantu seseorang memperoleh daya (kuasa) untuk mengambil keputusan dan menentukan tindakan yang akan ia lakukan yang terkaitdengan diri mereka untuk mengurangi efek hambatan pribadi dansosial dalam melakukan tindakan.

\section{Faktor-faktor Penghambat Evaluasi Program Pemberdayaan Masyarakat Melalui Bank Sampah Mawar Bestari di Kelurahan Sijambi Kecamatan Datuk Bandar Kota Tanjung Balai}

a. Faktor internal

Faktor internal yang menjadi kendala evaluasi program pemberdayaan masyarakat melalui Bank Sampah Mawar Bestari di Kelurahan Sijambi Kecamatan Datuk Bandar Kota Tanjungbalai dalam pelaksanaan pemberdayaan ialah motivasi, usia, pekerjaan, dan jenis kelamin yang dimiliki masyarakat (Halua'na \& Sembiring, 2016). Motivasi merupakan hal penting yang harus dimiliki oleh masyarkat ketika mengikuti suatu kegiatan. Berdasarkan hasil observasi dilapangan bahwa motivasi yang dimiliki masyarakat terhadap kegiatan pemberdayaan pemungutan sampah 
rumahan yang dilaukan oleh kelompok Bank Sampah Mawar Bestari dapat dikatakan masih kecil, hal tersebut dapat diketahui dari partisipasi yang diberikan masyarakat pada pelaksanaan program (Suryani \& Suharyanto, 2016). Sehingga dapat disimpulkan bahwa motivasi yang minim menjadi kendala dalam pelaksanaan pemberdayaan.

Faktor motivasi, faktor usia juga mempengaruhi pelaksanaan pemberdayaan, dimana dari hasil penelitian warga belajar yang mengikuti pemberdayaan rata-rata usia masyarakat tersebut 45 tahun. Sedangkan masyarakat berpartisipasi dalam pelaksanaan pemberdayaan hanya pada beberapa kegiatan, yaitu pada pembelajaran, pada usia 40 tahun keatas masyarakat mengakui bahwa kemampuan mereka dalam menyimak materi kurang baik hal tersebut juga dipengaruhi tingkat pendidikan masyarakat. hal tersebut dapat disimpulkan bahwa usia masyarakat mempengaruhi dan menjadi kendala dalam pelaksanaan pemberdayaan. Selain motivasi dan usia, berdasarkan hasil penelitian faktor pekerjaan juga menjadi kendala pelaksanaan pemberdayaan, dimana masyarakat di Kelurahan Sijambi banyak yang memiliki pekerjaan, sehingga waktu untuk mengikuti pemberdayaan Bank Sampah Mawar Bestari masih dibawah rata-rata.

\section{b. Faktor Eksternal}

Dari sisi faktor ekternalnya bahwa masih terdapat faktor yang mempengaruhi pelaksanaan pemberdayaan, yaitu masih kurangnya peran masyarakat dalam melaukan tindakan yang dibuat oleh pihak Kelurahan Sijambi dalam sosialisasi yang diakibatkan kesibukan masing-masing, mereka hanya melakukan pemungutan sampah yang dianjurkan piha Kelurahan, jika untuk bergabung dalam program pemberdayaan masyarakat melaui Bank Sampah keinginan masyarakat masih berkurang.

\section{SIMPULAN}

Evaluasi Program Bank Sampah Mawar Bestari di Kelurahan Sijambi dapat dikatakan berjalan optimal, dimana tujuan Bank Sampah Mawar Bestari mampu mewujudkan kerjasama yang baik antara pihak Kelurahan dengan masyarakat sehingga program Bank Sampah terlaksana dengan baik dan pemanfaatannya sangat dirasakan oleh masyarakat itu sendiri khususnya masyarakat Kelurahan Sijambi. Proses evaluasi program pemberdayaan masyarakat melalui Bank Sampah Mawar Bestari pihak kelurahan mampu menciptakan proses yang baik dimana dengan dibentuknya berbagai kelompok-kelompok masyarakat sehingga program Bank Sampah mampu terlaksana dengan baik, begitu juga dengan masyarakatnya, dengan melalui pelatihan-pelatihan yang dibuat oleh pihak Kelurahan Sijambi Kecamatan Datuk Bandar Kota Tanjungbalai, masyarakat sangat berantusias sekali mengikuti program-program yang bentuk oleh pihak Kelurahan.

Program pemberdayaan melalui pembentukan Bank Sampah Kelurahan Sijambi Kecamatan Datuk Bandar Kota Tanjungbalai masih mengalami kesulitan dari faktor internal dan eksternal, yaitu minimnya partisipasi masyarakat dalam program 
pemungutan sampah rumahan dan bergabung di komunitas Bank Sampah Mawar Bestari Kelurahan Sijambi Kecamatan Datuk Bandar Kota Tanjungbalai, walaupun pihak Kelurahan sudah melakukan berbagai sosialisasi, pertemuan-pertemuan, pelatihanpelatihan namun belum semua masyarakat bisa diajak untuk berpartisipasi dalam pengumpulan sampah-sampah rumahan, yang sementara pihak Kelurahan Sijambi sudah menyediakan lokasi dan tempat khusus pemungutan sampah serta berbagai alat-alat pengangkut sampah agar kepedulian msayarakat dengan sampah lebih perduli dengan kesehatan.

\section{DAFTAR PUSTAKA}

Alfitri. (2009). Kerusakan Lingkungan dan Masalah Sampah dari Prespektif Teori Sosiologi, 8, 30-32.

Anwas, O.M. (2014). Pemberdayaan Masyarakat di Era Global. Bandung: Alfabeta

Arikunto, Cepi. 2012. Evaluasi Program Pendidikan. Jakarta: Bumi Aksara.

Bungin. Burhan. (2012). Analisis Data Penelitian Kualitatif. Jakarta: Raja Grafindo. Persada.

Cholisin. (2011). Pemberdayaan Masyarakat. Makalah disajikan.

David, Fred, R. (2012). Strategic Management Manajemen Strategi Konsep. Jakarta: Salemba Empat. Goysen, Sunartiningsih, A. (2002). Pemberdayaan Masyarakat Desa. Yogyakarta: AdityaMedia.

Hikmat, H. (2006). Strategi Pemberdayaan Masyarakat. Bandung: Humaniora Utama

Hempri \& Suparjan. (2013), Era Globalisasi Community Development, Yogyakarta: Pustaka Pelajar

Huraerah, Abu. (2011). Program Pelaksanaan Pelatihan. Jakarta: Alfabeta.

Manik, Karden Eddy Sontang. (2007). Pengelolaan Lingkungan Hidup. Jakarta: Penerbit Djambatan.

Mardikanto, T \& Soebiato, P. (2015). Pemberdayaan Masyarakat dalam Prespektif Kebijakan Publik. Bandung: Alfabeta

Moleong, Lexy J. (2012). Metodologi Penelitian Kualitatif. Bandung: Remaja Rosdakarya

Mulyatiningsih, (2011). Evaluasi Proses Suatu. Program. Jakarta: Bumi Aksara.

Mardikanto, Totok. (2014). CSR (Corporate Social Responsibility) (Tanggungjawab Sosial Korporasi). Bandung: Alfabeta.

Nasution, Zulkarimein. (2014). Komunikasi Pembangunan, Pengenalan Teori dan Penerapannya. Jakarta: Rajawali.

Sejati, Kuncoro. (2009). Pengolahan Sampah Terpadu dengan Sistem Nude, Sub Point, Center Point. Yogyakarta: Penerbit Kanisius.

Rogers, E.M. \& Shoemaker, F.F. (2012). Communication of Innovations. Jakarta: Salemba Humanika.

Soebianto, Totok Mardikanto \& Poerwoko. (2012). Pemberdayaan Masyarakat dalam Perspektif Kebijakan Publik. Bandung: Alfabeta.

Soekanto, Soerjono. (2013). Sosial Suatu Pengantar. Jakarta: Rajawali press.

Sucipto, Cecep Dani. (2012). Teknologi Pengolahan Daur Ulang Sampah. Yogyakarta: Gosyen Publishing.

Suharto, Edi. (2014). Membangun Masyarakat Memberdayakan Masyarakat, Kajian Strategis Pembangunan Kesejahteraan Sosial \& Pekerjaan Sosial. Bandung: Refika Aditama

Sulistiyani, Ambar Teguh. (2014). Kemitraan dan Model-model Pemberdayaan. Yogyakarta: Gama Media.

Suparjan \& Hempri Suyato. 2003. Pengembangan Masyarakat, dari Pembangunan sampai Pemberdayaan. Yogyakarta: Aditya Media.

Sukardi, (2014). Evaluasi Program Pendidikan dan Kepelatihan. Jakarta: Bumi Aksara.

Suwerda, Bambang. (2012). Bank Sampah (Kajian Teori dan Penerapan) Disertai Penerapan Bank Sampah "Gemah Ripah" di Dusun Badegan Bantul. Yogyakarta: Pustaka Rihama.

WB, Isaac S \& Michael. (2010). Handbook in Research and evaluation. California: Edits Publishers.

Wirawan. (2011). Evaluasi Teori Model Standar Aplikasi dan Profesi, Contoh Aplikasi Evaluasi Program: Pengembangan Sumber Daya Manusia, Program Nasional Pemberdayaan Masyarakat (PNPM) Mandiri Pedesaan, Kurikulum, Perpustakaan, dan Buku Tes. Jakarta: Raja Grafindo Persada.

Winarno, Budi. (2010). Teori dan Proses Kebijakan Publik. Yogyakarta: Media. Pressindo.

Wintoko, Bambang. (2013). Panduan Praktis Mendirikan Bank Sampah, Keuntungan Ganda Lingkungan Bersih dan Kemapanan Finansial. Yogyakarta: Pustaka Baru Press.

Siregar, A.B., Kusmanto, H. \& Isnaini. (2016), Evaluasi Kinerja Kepala Sekolah Menengah Kejuruan SeKabupaten Langkat Tahun 2015, Jurnal Administrasi Publik, 6 (1): 13-19

Gowasa, I. \& Ritonga, S. (2015). Implementasi Program Raskin Untuk Membantu Perekonomian Masyarakat Miskin Di Kecamatan Tanah Masa Kabupaten Nias Selatan, Jurnal Administrasi Publik Universitas Medan Area, 3 (2): 97-111 
Suryani, A.I., \& Suharyanto, A, (2016). Implementasi Program Badan Penyelenggara Jaminan Kesehatan (BPJS) Dalam Meningkatkan Pelayanan Administrasi Kesehatan di Rumah Sakit Umum Sibuhuan Kabupaten Padang Lawas, Jurnal Administrasi Publik Universitas Medan Area, 4 (1): 86-

Halua'na, K. \& Sembiring, W.M. (2016). Eksistensi Seksi Ketentraman Dan Ketertiban Dalam Menunjang Program Pemerintah Daerah, JPPUMA: Jurnal Ilmu Pemerintahan dan Sosial Politik UMA (Journal of Governance and Political UMA), 4 (1): 11-23. 